\author{
Wilken ENGELBRECHT \\ ORCID: 0000-0002-9058-8199 \\ Univerzita Palackého v Olomouci \& Katolicki Uniwersytet Lubelski
}

\title{
Zwermen mensen en véél water - Tsjechen over het Nederlandse landschap
}

\begin{abstract}
The paper concerns the image of Dutch scenery in several travel messages of Czech people from the 17th through the 20th centuries. The paper starts with the presentation of two diaries written in the 17th century by the Counts Sternberg and the Protestant Hartmann. One of the first real Czech tourists of the 19th century (Josef Štolba) is the third author discussed in this study. Then, the paper focuses on the better-known writer Karel Čapek and ends with the discussion of two 20th-century travellers. The paper aims to show which elements are constant in the Czech picture of the Dutch landscape throughout the centuries.
\end{abstract}

Keywords: Low Countries, travel diaries, image, Čapek, Hartmann, Kubka, Skrbek, Sternberg, Štolba.

\section{Inleiding}

Bij gelegenheid van het jubileum van de Praagse neerlandistiek (2007) heeft de auteur verslag gedaan van het beeld van de Lage Landen in 17e-eeuwse reisverslagen uit de Boheemse landen (Engelbrecht 2008). Hoewel deze reizigers van verschillende afkomst waren, kwam er een eensluidend beeld naar voren van een georganiseerd land met prachtige steden en een geordend platteland. Het openbaar vervoer (trekschuit) en de relatief schone herbergen werden geprezen. Daar tegenover stond een negatiever beeld van de Nederlander zelf: onbeleefd en wel erg recht op de man af.

Dit beeld komt aardig overeen met de schets die Ellen Krol (2007: 142-145) geeft in Imagology: de wijze waarop Nederlanders hun land hebben ingepolderd wekt bewondering, zo is een kunstmatig en buitengewoon geordend landschap ontstaan. Sinds de zestiende eeuw is de Nederlandse reinheidszin spreekwoordelijk. 
De maatschappij is tamelijk egalitaristisch met een kennelijke neiging om autoriteit te negeren. Engelsen beelden Nederlandse kooplui af als gierige, onbetrouwbare types, in toneelstukken speelt de Hollander vaak de rol van een luidruchtige dronkenlap. Duitsers zien Nederlanders als een volk van wat benepen kruideniers in een kunstmatige door mensen geschapen omgeving gespeend van romantiek.

In deze bijdrage bekijken we in hoeverre dit zeventiende-eeuwse Tsjechische imagologische beeld in diachroon opzicht consistent is. Imagologie is hier in navolging van Joep Leerssen in diens overzichtsartikel Imagology. History and Method in Beller \& Leerssen (2007) gedefinieerd als een kritische studie van de representatie van een volk (in casu Nederlanders) door leden van een ander volk (in casu Tsjechen) om te ontdekken welk 'verbeeld discours' (imaginated discourse, Leerssen 2007: 27-28) is ontstaan. Hierbij is het Nederlandse landschap, speciaal de polder, als focuspunt genomen.

In de zeventiende eeuw was een peregrinatio academica naar de Republiek der Verenigde Provinciën voor protestantse jongeren vrij gebruikelijk. De hier besproken gebroeders von Sternberg die in mei en juni 1663 Nederland bereisden, wijken in zoverre af dat zij als katholieken naar Nederland kwamen. De protestantse geestelijke en academicus Adam Samuel Hartmann (1627-1691) kwam in 1657 naar Nederland om financiële ondersteuning voor de Boheemse Broederkerk te vragen.

Het reizen omwille van het reizen werd in de tweede helft van de negentiende eeuw mogelijk met de opkomst van de spoorwegen. Josef Štolba (1846-1930) bezocht als huisleraar van de adellijke Desfours Nederland en als gesettelde notaris deed hij Nederland in 1895 nogmaals aan, nu doelbewust als toerist in het gezelschap van zijn echtgenote en schoonmoeder. Over deze tweede reis publiceerde hij Na půdě moři urvané. Črty z výletu do Holandska [Op aan de zee ontrukte bodem. Schetsen van een uitstapje naar Holland, 1896] dat lange tijd het Tsjechische beeld van Nederland bepaalde. Het boekje Obrázky z Holandska [Prenten uit Holland] dat de bekendste vooroorlogse Tsjechische schrijver Karel Čapek (1890-1938) in 1931 maakte, verving dat van Štolba als belangrijkste impressie van Nederland en wordt in Tsjechië nog steeds geciteerd als er over Nederland wordt gesproken.

Eind jaren twintig bezocht de schilder Jaroslav Skrbek (1888-1954) Nederland in het kader van een langere studiereis. In zijn boekje Maliř na cestách [Een schilder op reis, 1929] beschreef hij de Scandinavische landen, Nederland en België. De laatst besproken reiziger is František Kubka (1894-1964) die in de jaren vijftig als communistisch verslaggever Nederland bezocht. Zijn verslag uit 1958 is de laatste hier geciteerde beschrijving van Nederland. Aan de hand van citaten uit de genoemde reisbeschrijvingen bekijken we in hoeverre een bepaalde nationale karakteristiek van Nederland door deze Tsjechische reizigers is geconstrueerd. Van alle reizigers is een korte levensbeschrijving gegeven. 


\section{De gebroeders von Sternberg}

De broers Wenzel Balthasar Adalbert (1643-1708), Johann Norbert (1644-1678) en Ignatz Karl Graf von Sternberg (ca. 1645-1700) ${ }^{1}$ waren de zoons van Franz Karl Matthias (1612-1648), opperrechter van Bohemen, die tijdens de Zweedse belegering van Praag was doodgeschoten. Zijn weduwe had de kinderen vervolgens in de beste katholieke traditie opgevoed en had hen onder andere naar de katholieke universiteit van Leuven gestuurd. Aan het einde van hun studieverblijf maakten zij in mei 1663 onderweg naar huis een grotere tour door Noordwest- en Zuid-Europa. Het was gebruikelijk om van zo'n studiereis een dagboek bij te houden en er zijn dan ook verschillende van dit soort dagboeken uit de Tsjechische landen bewaard gebleven. ${ }^{2}$ De beschrijving van de onderhavige tocht is bewaard gebleven in een verzamelhandschrift met verslagen van de oudste broer in het Latijn (ff. $2^{\mathrm{V}}-18^{\mathrm{V}}$ ) en drie verslagen in het Tsjechisch (ff. 21-41, 43-87 en 88-197) die samen de reis naar Leuven ( 9 juni - 2 juli 1662), door de Nederlanden en Engeland tot Parijs (11 mei - 10 oktober 1663) en tenslotte door Frankrijk en Italië naar huis (10 oktober 1663 - 22 november 1664) betreffen. Het Tsjechische deel is kennelijk geschreven door een dienaar in opdracht van de efoor ${ }^{3}$ Johan Heinrich Pipius ( $\uparrow 1674)$. Ik ga hier van de indrukken van Wenzel Balthasar uit.

In 1663 waren de Spaanse Nederlanden na de Vrede van de Pyreneeën (1659) eindelijk rustig, zodat er vrijelijk tussen de Republiek en de Zuidelijke Nederlanden gereisd kon worden. Vanuit Leuven gingen de broers op 11 mei 1663 naar Brussel, waar ze een paar dagen bleven, vervolgens naar Namen (14 mei) en over de Maas naar Luik (16/17 mei). Ze deden de bekende abdij Herkenrode bij Hasselt aan waar ze een week bleven, om door te gaan naar Den Bosch (26/27 mei) en veelal per trekschuit Utrecht, Amsterdam (28/31 mei), verschillende NoordHollandse steden, Leiden en Den Haag (3/6 juni) aan te doen. Via Rotterdam, Dordrecht (6 juni), Geertruidenberg en Breda ging de reis verder naar Antwerpen (8/10 juni), op 11 juni waren de broers weer terug in Brussel, van waaruit ze via

${ }^{1}$ Biografische gegevens in Wurzbach 282-283 voor Wenzel Adalbert en Wurzbach 277 voor Ignatz Karl, voor de ouders Franz Matthias en Ludmila Benigna zie Wurzbach 273-274 en 279. Gegevens over Ignatz Norbert in de artikelen over zijn vader en broers, voorts in de database biblio. hiu.cas.cz van de Tsjechische Academie van Wetenschappen.

${ }^{2}$ Een goed overzicht geeft de inleiding op Česká touha cestovatelská [Het Tsjechische verlangen om te reizen] van Polišenský (7-32). De laatste jaren zijn er met name bij de vakgroepen geschiedenis van de universiteiten van Brno, Olomouc en Pardubice verschillende afstudeerwerken aan afzonderlijke dagboeken gewijd.

${ }^{3}$ De efoor was een huisleraar, vaak een pas afgestudeerde wetenschapper die zo ervaring opdeed. In het geval van de jongens werd een ervaren jurist meegestuurd. Johann Heinrich Pipius was in 1654 decaan van de rechtenfaculteit en in 1655 rector van de Praagse universiteit geweest en werd in 1659 raadsheer onder Ulrich Adolf Vratislav Reichsgraf von Sternberg (ca. 1627-1703), destijds Vice-President van het Hof. Deze was een achterneef van de vader van de jongens (Weingarten 118). 
Gent, Brugge en Duinkerken naar Calais gingen om op 19 juni 1663 de oversteek naar Engeland te maken.

De Republiek was vervoerstechnisch een hele verademing na de slechte wegen in het door onophoudelijke oorlogen verarmde Brabant. Wenzel beschrijft het oponthoud in Utrecht en de reis naar Amsterdam over de Vecht als volgt:

[28-5-1663] (...) In deze stad [Utrecht] bloeit ook een Universiteit, direct naast de Kathedraal. We hebben daar uit nieuwsgierigheid een college rechten en filosofie gehoord, waarna we zijn teruggekeerd voor de lunch. Na het eten gingen we aan boord van een schip dat ons over de Amsterdamse vaart door een paard getrokken daarheen leidde. Deze weg leek ons de mooiste van de hele Nederlanden, omdat de gebouwen die we aan weerszijden zagen, er even mooi als trots uitzagen. Er wonen daar echter gewone burgers en kooplui, zowel uit Utrecht als uit Amsterdam. Daartussenin liggen prachtige tuinen en aangename weiden. Via deze weg bereikten we, met onderweg tweemaal wisseling van het paard, Amsterdam dat op ongeveer 7 uur gaans van Utrecht ligt. We kwamen er rond 6 uur aan en in het gasthuis Den Ouden Bijbel kwartierden we ons in. Nadat we daar onze bagage hadden afgegeven, gingen we schepen kijken en kwamen 's avonds na achten weer thuis, waar we met het avondmaal de dag beëindigden (NKP Ms. VIII G 18, f. $10^{\mathrm{v}}-11^{\mathrm{r}}$ ).

Amsterdam wordt door vrijwel alle reizigers als het hoogtepunt van hun reis beschouwd. In de $17 \mathrm{e}$ eeuw waren andere bezienswaardigheden dan tegenwoordig van belang: men bezocht het weeshuis, het rasphuis en het dolhuis, 'sociale inrichtingen' die voor Centraal-Europeanen destijds ongeveer even wonderlijk waren, als de Walletjes nu op reizigers uit Centraal-Europa overkomen. Hoogst merkwaardig was voor de heren het ontbreken van paleizen, maar daar stond tegenover dat de straten schoon en geplaveid waren:

[29-5-1663] (...) De vorm van deze stad [Amsterdam] is eerder langgerekt dan rond. Wat betreft de gebouwen, denk ik, dat ik nog nooit een stad zag, die méér mooie huizen heeft. Zeker, er zijn veel steden met grotere, meer en mooiere paleizen, maar toch kunnen ze deze stad niet evenaren, waar gewoon geen lelijke gebouwen bestaan. (...) Alle brede straten zijn voor het gemak van de voetganger aan beide kanten met vlakke witte vierkante stenen bestraat, ertussenin zijn mooie linden geplant die schaduw geven. Weliswaar zijn ze alleen langs straten geplant, waar middenin kanalen zijn, maar er zijn daar weinig straten waar géén kanalen zijn (NKP Ms. VIII G 18, f. $12^{\mathrm{r}}-12^{\mathrm{V}}$ ).

Niet alleen de trekschuit was comfortabel, toen de jongens met hun efoor en bediende na een aangenaam verblijf in Leiden laat op de dag in Den Haag aankwamen, bleken de betere gasthuizen allemaal vol te zijn. Ze moesten tot hun ongenoegen uitwijken naar een gewone herberg, maar werden aangenaam verrast:

[3-6-1663] (...) Vanuit Leiden kwamen we na ongeveer 4 uur reizen per trekschuit tussen weiden en gebouwen-in Den Haag aan. Vanwege de vele reizigers waren alle betere gasthuizen al vol en we moesten genoegen nemen met de herberg De Stad Leiden, waar echter de bedden aangenaam en schoon bleken te zijn, ook de keuken, waar we heel veel hongerige en dorstige reizigers hun eten zagen gebruiken (NKP Ms. VIII G 18 , f. $12^{\mathrm{r}}-12^{\mathrm{V}}$ ). 
Kennelijk beviel deze noodoplossing goed, want ze zagen geen noodzaak om gedurende hun driedaagse verblijf in Den Haag te verhuizen. Hun dagboek bevestigt het beeld dat Ellen Krol schetste: een egalitair land van burgers dat schoon en ordentelijk is. Omdat de gebroeders vooral bij beter gesitueerden te gast waren, vermelden zij nauwelijks iets over de lokale bevolking. Hun reis was bij uitstek toeristisch.

\section{Adam Samuel Hartmann}

$\mathrm{Nu}$ waren de Sternbergs geprivilegieerden met een kennelijk onuitputtelijke geldbuidel. Als 'gewone' mensen al reisden hadden ze noch de behoefte noch de kunde om dit op te schrijven. Een uitzondering vormden leden van de Tsjechische Broederuniteit. Deze was opgericht in 1457 door eenvoudige lieden die het radicale hussitisme afwezen. In de 16e eeuw groeide de Broederuniteit flink en gingen steeds meer intellectuelen deel uitmaken van deze pre-reformatorische kerk. In deze kerk ontstond de eerste complete Tsjechische bijbelvertaling, de Bible kralická [Kralitzer Bijbel] die in zes delen tussen 1579 en 1593 in Kralice werd gedrukt. ${ }^{4}$

De elite van de Broederuniteit was na 1625 uit Tsjechië verbannen en in Saksen of Polen terechtgekomen. ${ }^{5}$ Hun bisschop, Jan Amos Comenius (1592-1670) was in 1656 uitgeweken naar Amsterdam. Omdat de Nederlandse protestantse kerk vaak geloofsbroeders in het buitenland hielp, was Comenius het logische aanspreekpunt voor gemeenten uit de diaspora. Diens opvolger als rector van het gymnasium te Leszno, Adam Samuel Hartmann (1627-1691), werd naar Comenius toegestuurd toen na de verwoesting van Leszno in 1656 veel geld nodig was voor de wederopbouw. ${ }^{6}$ De reden om het verslag op te stellen was dat dit werd

${ }^{4}$ De vertaling van het Nieuwe Testament was al in 1564 in Ivančice gedrukt, waar in 15621578 de drukkerij van de Uniteit gevestigd was, voor deze naar Kralice verhuisde.

${ }^{5}$ Een deel van de broeders ging ondergronds in de moeilijk toegankelijke heuvels rond Fulnek en Suchdol. Onder leiding van Kristián David (1692-1751) emigreerden velen in 1722 alsnog naar Saksen, waar zij op het landgoed van Nikolaus Graf Zinzendorf (1700-1760) het stadje Herrnhut stichtten en in 1727 de Broederuniteit officieel heroprichtten. Van hieruit is door David o.a. de Nederlandse gemeente van de Moravische Broeders in Zeist (1745) gesticht, van waaruit de missie in Suriname en Zuid-Afrika ondersteund werd (beide missieposten waren in resp. 1735 en 1737 vanuit Herrnhut opgericht).

${ }^{6}$ De eerste Boheemse Broeders kwamen al in 1565 naar Leszno. In 1628 werd hun gemeente versterkt door honderden nieuwe emigranten die met Comenius mee kwamen. Tijdens de Noordse Oorlog (1655-1660) werd Leszno in 1655 door de Zweden bezet. In 1656 verjoegen Poolse katholieke partizanen de Zweden. Als straf voor de collaboratie van de plaatselijke protestanten werd de stad platgebrand. Comenius vluchtte vervolgens naar Nederland. De gegevens over Hartmann zijn gebaseerd op Sturm 543, Podmore 207-208 en de inleiding van Prümers. 
verwacht door de classis die de opdracht tot de reis had gegeven. Hartmann vermeldt dan ook minutieus met wie hij overal heeft gesproken.

Hartmann was geboren op 7 september 1627 in Praag, waar zijn vader consenior van de bekende Bethlehemkapel was. Zijn familie werd in 1628 uit Bohemen verbannen. Hartmann studeerde in Königsbergen, Frankfurt an der Oder en Leiden. Hij had dus concrete 'Nederlandervaring'. In 1651 werd hij leraar aan het gymnasium in Leszno. In 1657-1659 maakte hij de hier besproken reis en werd na zijn terugkomst senior in Liegnitz (Legnica). In 1663 was hij opnieuw rector van het gymnasium in Leszno. In 1673 werd hij tot 54 ${ }^{\mathrm{e}}$ bisschop van de Broederkerk gekozen ${ }^{7}$ en in 1680-1681 weer voor geld uitgestuurd, ditmaal naar Engeland. Bij die gelegenheid kreeg hij in 1681 het eredoctoraat van de universiteit van Oxford. In 1690 werd hij beroepen naar Memel (Klaipeda) en in 1691 van daaruit opnieuw naar Engeland uitgestuurd. Hij kwam echter niet verder dan Rotterdam, waar hij op 27 mei 1691 stierf. Het door hem geschreven handschrift met het reisverslag uit 1657-1659 is na de Tweede Wereldoorlog verloren geraakt (Polišenský 70). Hier is geciteerd naar de editie van Prümers (1899/1900).

Met weinig geld op zak vertrok het groepje van vier man op 15 mei 1657 uit Leszno. ${ }^{8}$ Vanuit Hamburg gingen zij op 14 juni verder over zee naar Amsterdam, waar ze op 29 juni aankwamen en hun opwachting bij Comenius maakten. Als de broeders op 10 juli naar Rotterdam willen vertrekken, houden zij zich te lang voor het afscheid bij Comenius op, waardoor zij hun trekschuit missen. Gelukkig bleek er een uurtje later een schip naar Delft te gaan, zodat ze met vertraging toch in Rotterdam aankwamen:

[10-7-1657] 's Namiddag om 1 uur zegenden we de heer Comenius en zijn huis, gingen we naar het schip, dat echter al gelost had (...). Derhalve hebben we nog eventjes moeten wachten en ons op het schip naar Delft gezet. Met dit schip zijn we weggezeild, goddank bij goede wind. We hadden een erg mooie reis, aan beide kanten dorpen of boerenhuizen, zeer prachtig, alleen van bakstenen gebouwd, daarbij ook tuinen en sappige weiden. Het is interessant dat de boeren merendeels apart wonen en aan alle kanten met kanalen omgeven zijn, zodat de een niet over land naar de andere kan komen. We makten bij het vallen van de nacht een pauze van een uurtje in een dorp. Hierna zeilden we verder, we kregen een paard dat naar het gebruik van dit land aan een touw ons schip moest trekken (zodat wij te paard over het water zijn gevaren) en we kwamen zo om 6 uur vroeg te Delft aan (Prümers 1899/1900: 258).

Na deze verrassend positieve ervaring met het lokale openbaar vervoer vonden zij in Zeeland Middelburg wel mooi, maar voor het overige de steden nogal

${ }^{7}$ Een complete lijst staat op de webpagina http://www.jbcr.cz/index.php/starajb.

${ }^{8}$ De anderen waren Paulus Cyrillus, Johann Elsner en Jan Zlinský. Cyrillus was de broer van Comenius' tweede echtgenote Marie Dorota $(\dagger 1648)$ en had in Bremen (1635) en in Groningen (1640) gestudeerd. In 1662 was hij leraar bij het gymnasium van Leszno. De familie Elsner was al in de 16e eeuw naar Leszno gekomen. Johann (ca. 1610-1687) was in 1652 acoliet. Over Zlinský zijn geen gegevens bekend. 
saai en de plaatselijke bevolking opdringerig. De vrijpostigheid van de jeugd, vooral van de meisjes valt hun op:

[21-7-1657] Daarna gingen we de stad [Zierikzee] bekijken, waarin niets speciaals was. We verbaasden ons echter over het volk zelf dat ons van zo dichtbij aangaapte, alsof ze een vreemd wonder zagen; velen bleven staan, anderen kwamen hun huis uitgelopen of staarden ons verbaasd door brillen aan. De straten zijn overal tamelijk breed, de huizen laag, allemaal eenvormig gebouwd, de ramen snoerstrak in één lijn geordend. De jeugd is daar nogal wild, er is een grote menigte jongeren, merendeels rood gekleed en ze schreeuwen op straat erg, gedragen zich als krijgsbenden. De meisjes (tamelijk groot) spelen met de jongens, springen touwtje, jagen honden achterna (...) (Prümers 1899/1900: 280).

Hartmann vindt de Hollanders en Zeelanders wel vaker nogal lawaaierig en lomp. Zeeland is bovendien duur en veel geld krijgen ze evenmin, een probleem dat ze vaker tegenkomen. Zijn notities bevestigen daarmee het door Krol genoemde stereotiepe Engelse beeld van de Hollander. Voor de zeventiende-eeuwers waren met name het efficiënte vervoerssysteem, de schone steden en het rijke platteland, het ontbreken van adel en grote paleizen en ook de zelfbewuste burgers typerend voor Nederland.

\section{Beginnend toerisme: Josef Štolba}

Dankzij de spoorwegen ontstond het moderne toerisme. Tsjechië werd in 1850 op het Europese net aangesloten en Tsjechen begonnen flink te reizen. Reisverhalen werden een geliefd genre. Josef Štolba (1846-1930) was in de tweede helft $19 \mathrm{e}$ eeuw een van de bekendste Tsjechische auteurs van dit genre. ${ }^{9}$ Hij werd geboren op 3 mei 1846 in de stad Hradec Králové in een gegoede burgerfamilie. In 1865-1869 studeerde hij in Praag rechten en nam daarna een baan aan als huisleraar bij de adellijke families Kaunitz en Desfours-Walderode. Dankzij deze job reisde hij tussen 1870 en 1874 door Europa, Azië en Noord- en Zuid-Amerika. $\mathrm{Na}$ terugkomst promoveerde hij, trouwde en vestigde zich als notaris. In 1890 werd hij notaris in Pardubice en na 1911 leefde hij als gepensioneerde in de wijk Královské Vinohrady te Praag, waar hij op 12 mei 1930 stierf. Ook als notaris reisde hij tijdens vakanties heel wat af. In zijn vrije tijd schreef hij een enorme hoeveelheid reisverhalen op basis van zijn ervaringen.

In Na půdě moři urvané [Aan de bodem van de zee ontrukt, 1896] beschreef hij zijn indrukken van Nederland van zijn tweede reis in 1895, deze keer met zijn vrouw en schoonmoeder gemaakt. In lijn met de titel van het werk beschreef hij hoe het Hollandse landschap ontstond:

${ }^{9}$ Gegevens op basis van Mazáčová. 
Hollands landschap maak je heel eenvoudig. Je neemt gigantische weiden, doorsnijdt die met zo regelmatig mogelijke grachten, niet al te breed, je vult die grachten, die in heel Holland een enorm netwerk vormen, met water, plant er op verschillende plekken rijen bomen en houtwallen, bij voorkeur wilgen, zodat ze vooral de horizon mooi vullen, dan strooi je zo hier en daar wat windmolens uit, zet je op de weiden zoveel mogelijk prachtige Hollandse koeien neer, die dankzij de sloten die alle weiden begrenzen, niet zomaar door heel Nederland kunnen rondrennen - en je hebt een Hollands landschap, zoals zelfs Ruysdael het niet beter had kunnen schilderen (Štolba 1896: 38). ${ }^{10}$

Het landschap wordt dus beschreven als uitermate regelmatig en als een esthetisch geheel, een schilderij van Ruysdael. Maar diezelfde eenvoud maakt de steden vrij saai:

De huizen, op enkele te verwaarlozen uitzonderingen na, hebben meestal drie, vier of vijf verdiepingen, ze hebben een hopeloos eenvoudig uiterlijk, zijn meestal van baksteen en zonder enige architectonische versiering en merendeels ook zonder stuc die het wellicht vanwege de vochtige lucht niet lang zou uithouden (Štolba 1896: 43-44).

En het is er waanzinnig druk - "Overal dat drukke leven. Hier roept een groentenverkoper, daar een verkoper van keukengerei, dan weer een krantenjongen, en iedereen schreeuwt uit volle borst. Overal mensen als vliegen" (Štolba 1896: 45). Toch heeft hij wel bewondering:

Je kunt de Hollanders van alles verwijten, laat de wereld maar bitter lachen om hun eeuwige gesjacher, ja met het goud van handeldrijven is de Hollandse grond geplaveid, die aan de zee ontrukte grond - maar niemand kan hun zijn bewondering ontzeggen voor hun mierenwerk, dat minutieuze, onvermoeibare en eerlijke werk, waarmee zij zich bezighouden terwijl ze onophoudelijk vechten met de zee zelf om dat niet zo grote stukje land dat de Hollanders hun thuis noemen (Štolba 1896: 160).

Zijn verhaal komt aardig overeen met de indrukken van de reizigers die Nederland enkele eeuwen eerder bezochten. Het boekje werd in 1898 herdrukt en deed lang dienst als de belangrijkste Tsjechische beschrijving van Nederland.

\section{Karel Čapek}

Bijna veertig jaar later, toen intussen nieuwe verkeersmiddelen als de fiets en de automobiel waren uitgevonden, bezocht een andere reislustige Tsjech Nederland. Dit was Karel Čapek (1890-1938), internationaal bekend geworden als schepper van het begrip robot - uit zijn toneelstuk R.U.R. (1920). Zijn vader was arts in Mladé Svatoňovice in het Sudetengebergte waar Čapek op 9 januari 1890 werd geboren. ${ }^{11}$ In 1909-1915 studeerde hij te Praag filosofie, kunst, Frans, Duits en

${ }^{10}$ Behalve bij Karel Čapek zijn de vertalingen uit het Tsjechisch, Oudduits (Hartmann) en Latijn (Sternberg) van de hand van de auteur.

${ }^{11}$ Gegevens over Čapek op basis van Forst 1985. 
Engels. Van eind 1917 tot praktisch aan zijn dood was hij redacteur van verschillende tijdschriften en kranten, vanaf 1921 van de liberale krant Lidové noviny [Volkskrant].

Čapek was overtuigd liberaal en waarschuwde onder andere met zijn toneelstuk Bílá nemoc [De witte ziekte, 1937] tegen de gevaren van het nationaal-socialistische regime. Het 'Verdrag van München' (30 september 1938), waarbij de Duitstalige randgebieden van Tsjechoslowakije door het Derde Rijk werden geannexeerd, bezorgde hem een enorme depressie. Hij trok zich terug in zijn villa op het platteland, maar liep bij een overstroming een longontsteking op, waaraan hij op 25 december 1938 overleed. Hiermee ontkwam hij aan een door de Gestapo begin 1939 geplande arrestatie, waarbij zijn broer Josef (1887-1945), ook schrijver en illustrator, met wie Karel nauw samenwerkte, werd opgepakt. Josef stierf in april 1945 aan vlektyfus in Bergen-Belsen.

Čapek bezocht in 1931 voor het PEN-congres als Tsjechische afgevaardigde Nederland en legde daarvan verslag in zijn ettelijke keren herdrukte Obrázky z Holandska [Beelden uit Holland, 1931]. Zijn reisimpressies werden tweemaal in het Nederlands vertaald, de eerste keer door Eva Raedt-de Canter (ps. van Anna de Mooij, 1900-1975) ${ }^{12}$ als Over Holland (1933) en nogmaals in 2009 door de bohemist en literair vertaler Kees Merckx (geb. 1944) als Prenten uit Holland. Deze tweede vertaling is hier gebruikt.

Čapek kon iets zien, wat nog niet bestond toen Štolba reisde - de fiets. Dit 'oer-Hollandse' vervoermiddel vermengde zich met de al door Štolba genoemde bakstenen:

Mijn eerste zuiver Hollandse indrukken (...) waren bakstenen. En ramen. En vooral fietsen. En vooral bakstenen en ramen. Die bakstenen, dat is de lokale kleur van Holland: een groen landschap en erin huisjes van kleine rode, wit gevoegde bakstenen, huisjes met grote, heldere ramen en een groen landschap met wegen van baksteen, waarover zachtjes fietsen suizen van het éne huisje naar het andere (Čapek 13).

De fietsen maakten op Čapek een enorme indruk en hij wijdde er een hele reeks bladzijden aan, vaak voorzien van mooie tekeningetjes:

En dan die fietsen dus. Ik heb er al heel wat gezien, maar zóveel fietsen als bijvoorbeeld in Amsterdam, heb ik nog nooit gezien; dat is niet zomaar hier en daar een fiets, maar iets massaals: scholen, zwermen, kolonies rijwielen (...). Ik heb nonnen op de fiets gezien en boeren die met een koe aan de hand fietsten; mensen die een hapje op de fiets verorberen en die kinderen en honden erop vervoeren, en verliefde stelletjes die hand in hand een schitterende toekomst tegemoet fietsen; ik zeg u, voorwaar, dit hele volk zit op de fiets (Čapek 14-15).

12 Eva Raedt-de Canter was in de jaren 30 verbonden aan het tijdschrift Groot Nederland en kwam zo in contact met Čapek tijdens diens verblijf in Nederland. Zij heeft verschillende werken van hem in het Nederlands vertaald. Vele daarvan zijn in de laatste decennia opnieuw vertaald. Hier is geciteerd naar de vertaling van Kees Merckx. 
Ook Čapek wijdde zich aan het fenomeen polder:

Wel, ik heb met eigen ogen gezien, hoe Holland gemaakt wordt. Het gaat net als bij die steden: je neemt een stuk zee, je dijkt het in en pompt het leeg; dan blijft de bodem over, waarvoor een flink stuk Europa via zijn rivieren zijn beste modder levert en de zee fijn zand, de Hollander legt dat droog en zaait er gras op, koeien grazen er, de Hollander melkt ze en maakt van de melk kaas die in Gouda of Alkmaar naar Engeland wordt verkocht; wat trouwens een mooi voorbeeld is van de kringloop der materie (Čapek 32).

Čapeks beeld sluit aan bij dat van Štolba. Ook bij hem is veel aandacht gewijd aan de inpoldering en het als gevolg van inpoldering ontstane enigszins monotone landschap. De indruk van massaliteit die de Nederlandse bevolking maakt, wordt bij Čapek verbonden met het fenomeen fiets.

\section{Jaroslav Skrbek}

Een schilder kijkt anders dan 'gewone' mensen. Jaroslav Skrbek (1888-1954) was een leerling van de in Tsjechië bekende Max Švabinský (1873-1962), een wat Jan Toorop-achtige schilder. Skrbek schilderde vooral landschappen en maakte eind jaren twintig enkele studiereizen door Europa, onder andere naar Nederland en België. ${ }^{13}$ Van die reizen is een boekje Malír na cestách [Schilder op reis] uitgekomen. Afgezien van de obligate opmerkingen over grachten en polders is interessant hoe Skrbek het heien beschrijft:

Amsterdam ligt aan de oever van de Zuiderzee op modderige grond, aan kanalen die de stad in een halve cirkel doorsnijden en dan weer dwarsdoor naar het centrum. De gebouwen hebben geen fundamenten, ze staan allemaal op houten palen, heel gewone dennestammen, zelfs grote paleizen als het Koninklijk Paleis (15600 palen) niet uitgezonderd. Tegenwoordig gebruikt men gewapend beton, voor ons onbegrijpelijk, als we bedenken hoe zorgvuldig Tsjechische bouwers een stevige ondergrond uitzoeken, bijv. op de Moldau-oever. Ik zag een voor nieuwbouw gesloopt complex en keek vanaf de stoep naar beneden in de modder; daar heiden ze heel primitief, zonder stoomhamers, lange houten stammen in de modder - de één naast de ander, zonder zichtbaar plan, zelfs de koppen staken er ongelijk uit (die zagen ze achteraf op dezelfde hoogte af); ze gooiden er een gevlochten metaalmatras overheen, maakten een vloer van gewapend beton en zie, er werd al de hoogte in gebouwd (Skrbek 1929: 75).

De woorden onbegrijpelijk, primitief en zonder zichtbaar plan wijken nogal af van de zorgvuldige planning die Štolba en Čapek beschrijven. Bij het lezen komt de indruk op dat Škrbek Nederland een overdreven geordend en ongezellig land vond.

De tekeningen in zijn boekje zijn perfecter dan die van de amateur Čapek, maar missen de trefzekere Schwung van diens schetsjes. Zelfs als Skrbek mensen afbeeldt, komen die niet echt tot leven. Dat lag wellicht ook aan zijn gevoelens,

13 Gegevens op basis van Bašta. 
want bij zijn bezoek in Brussel verzuchtte Skrbek dat hij eindelijk het gevoel had, levende mensen tegen te komen:

De binnenstad (...) is een echt contrast met Den Haag en Amsterdam voor een op gezelschap gestelde persoon - vol grote cafés, de winkels zijn tot elf uur's nachts open, de vrouwen zijn teerder in hun bewegingen, flexibeler, elegant, alles staat ons hier meer na dan die Hollandse kloosteratmosfeer. Hier en daar gooit bijna iedereen (ook zo te zien wel opgevoede mannen en vrouwen) schaamteloos een uitgegeten ijswafel op straat, de cafétafeltjes zijn vaak wat plakkerig van een aperitief of een limonade, met wat stof - maar in de bedrijvigheid merk je dat niet; overigens hebben niet ook wij thuis bij de grote drukte op de jaarbeurzen, waar de tijd vliegt en de gasten elkaar afwisselen, dezelfde situatie? Ten slotte is in die Duitse onderwijzersordentlijkheid en Hollandse overdreven netheid niet de volledige zin van het leven en die landen geven geen mogelijkheden om je geest zo te ontwikkelen als België of Frankrijk (Skrbek 1929: 93).

Škrbeks beschrijving is een echo van de door Krol (2007: 143) gesignaleerde Duitse opvatting over een benepen kruideniersmentaliteit van de Nederlanders.

\section{František Kubka}

De journalist František Kubka (1894-1969) moest in 1914 als student onder de wapenen. ${ }^{14}$ Hij werd aan het Russische front krijgsgevangen gemaakt. Uiteindelijk werd hij in december 1918 door Tsjechische legionairs bevrijd uit het concentratiekamp Berezovka nabij de Mongoolse grens. Hij trad toe tot het legionairsleger en zette in 1920 in Charbin in Mantsjoerije een lokale afdeling van de christelijke jongerenorganisatie YMCA op. Als een van de laatste Tsjechische legionairs werd hij in mei 1921 gerepatrieerd, waarna hij zijn studie kon afmaken.

In 1922-1927 was hij secretaris van de Praagse YMCA, vervolgens tot 1937 redacteur buitenland bij de Prager Presse. ${ }^{15}$ Vlak voor de oorlog was Kubka hoofdambtenaar bij het ministerie van buitenlandse zaken. Als 'politiek onbetrouwbaar' werd hij in april 1939 ontslagen en tussen november 1939 en april 1940 door de Gestapo in Berlijn geïnterneerd. Na terugkomst werd hij aangesteld op het ministerie van onderwijs. Na een korte periode als ambassadeur van Tsjechoslowakije in Sofia (1946-1949) was hij tot zijn dood schrijver van beroep. In zijn historische romans en reisverhalen trachtte Kubka een 'socialistische' kijk op de geschiedenis en de wereld te verenigen met zijn oorspronkelijke protestantschristelijke ideeën.

14 Gegevens op basis van Lantová.

15 Dit was een door president Masaryk in 1921 opgezet Duitstalig blad dat als doel had om de Duitstaligen te integreren. Het werd ondersteund door het Tsjechoslowaakse ministerie van buitenlandse zaken en werd in 1938 opgeheven. 
Hoewel Kubka al voor de oorlog als secretaris van de YMCA Nederland bezocht, duurde het tot 1958 voor zijn reisnotities in boekvorm uitkwamen. Dat was al onder het communisme. De voorheen overtuigd christelijke en liberale journalist en ambtenaar had zich na 1949 laten 'overtuigen' van de 'juiste weg' van het socialisme. Zodoende mocht hij verder reizen en schrijven. In de jaren vijftig bezocht hij Nederland voor de tweede keer.

Het zesde deel van zijn werken bevat reisverhalen uit Engeland, Nederland, Finland, de DDR en de Sovjet-Unie. Dit alles in de destijds 'politiek-correcte' verhoudingen: hoewel het bandje met Nederland begon, zijn slechts zeven van de ruim 350 pagina's aan Nederland gewijd. Van het oorspronkelijke verslag is eigenlijk alleen zijn bezoek aan het Huisje van Tsaar Peter in Zaandam overgebleven, terwijl ruim 300 pagina's aan de Sovjet-Unie waren gewijd. Maar wát afgedrukt is, geeft wel een indruk van Kubka's oorspronkelijke impressies:

Met de auto is het vanuit Amsterdam naar Zaandam maar een steenworp afstand. Direct achter het station moet je echter het Noordzeekanaal oversteken. Daarom duurt het even voordat de pont je over het water zet dat hier kort en begrijpelijk IJ heet. Maar dan ben je gelijk in een groen, groen landschap, het electrische treintje zoeft over de dijk en onder die dijk stroomt het riviertje de Zaan. In het riviertje weerspiegelen zich voortdurend een rij elzen, een vissersbootje en de hemel met één enkele wolk. De hemel glimt in de hemel en in het water als Delfts blauw en de wolk is zacht als een schapenvacht. Op de weiden rusten zwartwitte koeien uit - zoals op alle Hollandse weiden - en dat wat over het water nadert, is ofwel een windmolen of een aak. In elk geval iets langzaams, ouds en wijs (Kubka 1958: 7).

\section{Ook aan Kubka vallen de fietsen op:}

Hollanders lopen nooit. Ze staan of rijden. Vermoedelijk komen ze al met wieletjes op de wereld. Hollanders en Hollandse vrouwen rijden in rijen achter elkaar en praten. Hollanders en Hollandse vrouwen rijden in rijen naast elkaar en zwijgen. Hollandse jongens rijden in innige paren naast Hollandse meisjes en ze houden elkaar daarbij bij de hand. Hollandse jongens kussen op de fiets met Hollandse meisjes en kennelijk slapen ze zelfs op de fiets met hen (Kubka 1958: 7).

Tenslotte valt het hem op dat wegen soms ónder kanalen door gaan:

Omdat er in Holland ruimte genoeg is, kun je er betonnen en asfaltwegen en -weggetjes bouwen met tunnels, op- en afritten en afslagen naar alle kanten, zodat - omdat alles toch al onder zeeniveau ligt - je zowel boven als onder kanalen door kunt gaan, zonder dat het vreemd overkomt dat de barken met tulpenbollen ergens boven je hoofd langsvaren (Kubka 1958: 8).

Kubka's beelden zijn duidelijk geïnspireerd door die van Čapek en er wordt een tamelijk idyllisch, een beetje sprookjesachtig landschap geschetst. 


\section{Conclusie}

Hoe ziet Nederland er in Tsjechische ogen uit? Voor de bewoners van hoogland die de Tsjechen zijn, is het land zelf een rariteit: hoe kun je in vredesnaam op de bodem van de zee leven, daar een succes van maken en je er veilig bij voelen? De alomtegenwoordige bloemen en tuinen worden als positief ervaren. Nederlandse vervoersmethoden, vroeger de trekschuit, vanaf de $20 \mathrm{e}$ eeuw de fiets, roepen ook verbazing op.

In Tsjechische ogen is Nederland zeer georganiseerd. De Nederlandse properheid, rechtlijnigheid en netheid worden als spreekwoordelijk beschouwd, maar door sommigen als Škrbek ook als gebrek aan menselijkheid gezien. Bij de huizen valt op dat die eenvormig zijn, met grote ramen, bakstenen en dat versieringen vrijwel ontbreken.

In vroeger tijden werd vooral genoteerd dat de burger de maat der dingen lijkt te zijn en dat vrouwen op min of meer gelijke voet met mannen omgaan (en meisjes met jongens). Aan Hartmann en de Sternbergs viel al in de 17e eeuw op dat het grootste paleis in Nederland, het Paleis op de Dam, helemaal geen paleis maar een stadhuis was.

In vrijwel alle periodes valt de massaliteit op. Er zijn overal ontzettend veel mensen (fietsers) en ze zijn nogal nadrukkelijk aanwezig. Hiermee hangt in Tsjechische ogen ook een gebrek aan beleefdheid samen.

Tenslotte valt op dat voor vrijwel alle Tsjechische reizigers Nederland duidelijk synoniem is met de provincies Holland, Zeeland en eventueel nog Utrecht. De rest van het land komt nauwelijks in beeld. Het beeld van Nederland in Tsjechische reisschetsen is gedurende de beschreven drie eeuwen tamelijk consistent gebleven.

\section{Bibliografie}

Bašta, Jiří (2005): “Maliřri Krkonoš: Jaroslav Skrbek”. Časopis Krkonoše - Jizerské hory 11, 46-47. Čapek, Karel (z.j.): Prenten van Holland. Vertaald door Kees Merckx. Amsterdam: Voetnoot.

Engelbrecht, Wilken (2008): "Het 'achtste wereldwonder'. Nederland gezien door de ogen van Tsjechische reizigers in de zeventiende eeuw”. In: Zdenka Hrnčírová e.a. (ed.), Praagse Perspectieven 5. Praha: Universitas Carolina Pragensis, 301-324.

Forst, Vladimír (1985): "Karel Čapek”. In: Vladimír Forst (ed.), Lexikon české literatury 1. Praha: Academia, 381-386.

Handschrift Národní muzeum, Praag, VIII G 18 - reisverslag van de gebroeders Sternberg.

Krol, Ellen (2007): "Dutch". In: Manfred Beller \& Joep Leerssen (ed.), Imagology: The Cultural Construction and Literary Representation of National Characters. Amsterdam/New York: Rodopi, $142-144$.

Kubka, František (1958): Z cest. Praha: Československý spisovatel.

Lantová, Ludmila (1993): "František Kubka". In: Vladimír Forst (ed.), Lexikon české literatury 2, II. Praha: Academia, 1035-1038. 
Leerssen, Joep (2007): "Imagology: History and method". In: Manfred Beller \& Joep Leerssen (ed.), Imagology: The Cultural Construction and Literary Representation of National Characters. Amsterdam/New York: Rodopi, 63-76.

Mazáčová, Stanislava (2008): “Josef Štolba”. In: Luboš Merhaut (ed.), Lexikon české literatury 4, I. Praha: Academia, 771-774.

Podmore, Collin (1998): The Moravian Church in England, 1728-1760. Oxford: Clarendon Press.

Polišenský, Josef (1989): Ceská touha cestovatelská. Cestopisy, deníky a listy ze 17. století. Praha: Odeon.

Prümers, Rodgerus (1899/1900): “Tagebuch Adam Samuel Hartmanns über seine Kollektenreise im Jahre 1657-1659”. Zeitschrift der Historischen Gesellschaft für die Provinz Posen 14 (1899), 67-140, 241-308; 15 (1900), 94-160, 203-246.

Skrbek, Jaroslav (1929): Malír na cestách: Balkán, Holandsko, Belgie. Praha: Nová škola.

Štolba, Josef (1896): Na piodě moři urvané. Črty z výletu do Holandska. Praha: Fr. Bačkovský.

Sturm, Heribert (1979): Biographisches Lexikon zur Geschichte der böhmischen Ländern $(A-H)$. München/Wien: Oldenbourg Verlag.

Weingarten, Johann Jacob von (1690): Fasciculum diversorum iurium I. Nürnberg: Johann Zieger.

Wurzbach, Constant von (1879): Biographisches Lexikon des Kaiserthums Oesterreich, Bd. 38 (Stehlík-Stietka). Wien: k.k. Hof- und Staatsdruckerei. 